\title{
EVALUASI ECONOMIC VALUE ADDED (EVA), FINANCIAL VALUE ADDED (FVA) DAN MARKET VALUE ADDED (MVA) DENGAN TIME SERIES APPROACH SEBAGAI ALAT PENILAIAN KINERJA KEUANGAN (Studi Pada PT. Garuda Indonesia Tbk Periode 2015-2019)
}

\author{
Diyanti Rifal Agustin \\ Fakultas Ekonomi dan Bisnis, Universitas Muhammadiyah Jember \\ rifaldiyanti91@gmail.com \\ Ni Nyoman Putu Martini \\ Fakultas Ekonomi dan Bisnis, Universitas Muhammadiyah Jember \\ martini_nyoman@yahoo.co.id \\ Tatit Diansari Riskiputri \\ Fakultas Ekonomi dan Bisnis, Universitas Muhammadiyah Jember \\ tatit.diansari@unmuhjember.ac.id
}

\begin{abstract}
Background - Financial performance is a company's work performance that has been achieved in a certain period and can be seen in the financial statements of the company concerned. Financial statement analysis using conventional methods is often used by companies to measure their financial performance, namely financial ratio analysis. PT Garuda Indonesia Tbk, must have the option to create value added or

Diterima : 05 Juni 2021

Direview : 15 Juni 2021

Direvisi : 25 Juli 2021

Disetujui : 30 September 2021 large profits and create or add value to the capital that has been donated to meet the assumptions for financial backers (financial backers or investors).

Purpose - Measure financial performance with Economic Value Added (EVA), Financial Value Added (FVA) and Market Value Added (MVA)

Design/ Methodology/ Approach - This is a descriptive research with a quantitative approach. Sources of data in this study using external secondary data sources obtained through literature study which is arranged in the form of documents in the form of financial reports. The analysis technique in this study uses Time Series Analysis

Results and Discussion - EVA measurement with a time series approach from 2015-2019 the average EVA is -25,291,800.85, this indicates that the company has not been able to provide added value to shareholders because EVA is negative $(E V A<0)$ so it is said to perform Not Good. Measurement of FVA with a time series approach from 2015-2019 the average FVA is 21,359,193.35, this indicates that the company is able to provide added financial value for companies and investors because the FVA value is Positive (FVA>0) so it is said to be performing well. MVA measurement with a time series approach from 2015-2019 the average MVA is 9,019.927,024,116, this indicates that the company is able to provide added value because the MVA value is Positive (MVA>0) so it is said to be performing well.

Conclusion - EVA, FVA, and MVA values in 2015 were positive, in 2016 EVA and FVA were negative while MVA was positive, in 2017 EVA was negative while FVA and MVA were positive, in 2018 EVA was negative, FVA and MVA were positive, in 20182019 EVA, FVA, and MVA are positive.

Research Implications - The research results in this study can be considered by the management of PT Garuda Indonesia in assessing and evaluating the company's financial performance.
\end{abstract}

Keywords : Financial Performance, Economic Value Added, Market Value Added, Financial Value Added

Abstrak

Latar Belakang - Kinerja keuangan merupakan prestasi kerja perusahaan yang berhasil dicapai dalam 
suatu periode tertentu dan terlihat pada laporan keuangan perusahaan yang bersangkutan. Analisis laporan keuangan dengan metode konvensional yang sering dilakukan perusahaan untuk mengukur kinerja keuangannya yaitu analisis rasio keuangan. PT Garuda Indonesia Tbk, harus memiliki pilihan untuk membuat nilai tambah atau keuntungan besar dan membuat atau menambah nilai modal yang telah disumbangkan untuk memenuhi asumsi untuk pendukung keuangan (pendukung keuangan atau investor).

Tujuan - Mengukur kinerja keuangan dengan Economic Value Added (EVA), Financial Value Added (FVA) dan Market Value Added (MVA)

Desain/ Metodologi/ Pendekatan - Merupakan penelitian deskriptif dengan pendekatan kuantitatif. Sumber data penelitian ini menggunakan sumber data sekunder eksternal diperoleh malalui studi kepustakaan yang tersusun dalam bentuk dokumen yaitu berupa laporan keuangan. Teknik analisis dalam penelitian ini menggunakan Time Series Analysis

Hasil dan Pembahasan - Pengukuran EVA dengan pendekatan time series dari tahun 2015-2019 ratarata EVA adalah sebesar -25.291.800,85 hal ini mengindikasikan bahwa perusahaan belum mampu memberikan nilai tambah bagi para pemegang saham karena EVA bernilai Negatif $(E V A<0)$ sehingga dikatakan berkinerja Tidak Baik. Pengukuran FVA dengan pendekatan time series dari tahun 20152019 rata-rata FVA adalah sebesar 21.359.193,35 hal ini mengindikasikan bahwa perusahaan mampu memberikan nilai tambah financial bagi perusahaan dan investor karena nilai FVA bernilai Positif $(F V A>0)$ sehingga dikatakan berkinerja Baik. pengukuran MVA dengan pendekatan time series dari tahun 2015-2019 rata-rata MVA adalah sebesar 9.019.927.024.116, hal ini mengindikasikan bahwa perusahaan mampu memberikan nilai tambah karena nilai MVA bernilai Positif (MVA $>0)$ sehingga dikatakan berkinerja Baik.

Kesimpulan - Nilai EVA, FVA, dan MVA ditahun 2015 bernilai positif, ditahun 2016 EVA dan FVA negatif sedangkan MVA bernilai positif, ditahun 2017 EVA bernilai negatif sedangkan FVA dan MVA bernilai positif, ditahun 2018 EVA bernilai negatif, FVA dan MVA bernilai positif, ditahun 2019 EVA, FVA, dan MVA bernilai positif.

Implikasi Penelitian - Hasil penelitian dalam kajian ini dapat dipertimbangkan oleh manajemen PT Garuda Indonesia dalam menilai dan mengevaluasi kinerja keuangan perusahaannya.

Kata Kunci : Kinerja Keuangan, Economic Value Added, Market Value Added, Financial Value Added

\section{PENDAHULUAN}

Ikatan Akuntansi Indonesia menyatakan bahwa Laporan Keuangan adalah struktur yang menyajikan posisi keuangan dan kinerja keuangan adalah sebuah entitas. Tujuan umum dari laporan keuangan ini untuk kepentingan umum adalah penyajian informasi mengenai kinerja keuangan (financial performance), posisi keuangan (financial position), dan arus kas (cash flow) sangat berguna untuk membuat keputusan ekonomis bagi para penggunanya. Laporan Keuangan juga menggambarkan hasil usaha suatu perusahaan pada saat tertentu atau jangka waktu tertentu dan menggambarkan kondisi keuangan perusahaan. Adapun jenis laporan keuangan yang lazim dikenal adalah laporan arus kas, laporan laba rugi, atau hasil usaha, neraca, laporan perubahan posisi keuangan. (Harahap 2013). Laporan Keuangan digunakan untuk melihat kinerja keuangan perusahaan.

Kinerja keuangan merupakan prestasi kerja perusahaan yang berhasil dicapai dalam suatu periode tertentu dan terlihat pada laporan keuangan perusahaan yang 
bersangkutan. Penilaian kinerja dilakukan oleh pihak manajemen yang merupakan salah satu cara agar dapat memenuhi kewajibannya terhadap para penyandang dana dan juga untuk mencapai tujuan yang telah ditetapkan oleh perusahaan (Rahayu 2010).

Kinerja Keuangan merupakan salah satu bentuk tanggung jawab pihak manajemen terhadap pemilik perusahaan. Manajemen dapat berinteraksi dengan lingkungan dalam maupun luar perusahaan melalui informasi. Informasi tersebut lebih lanjut dirangkum dalam laporan keuangan perusahaan. Pada umumnya analisis laporan keuangan dengan metode konvensional yang sering dilakukan perusahaan untuk mengukur kinerja keuangannya yaitu analisis rasio keuangan. Praktiknya walaupun analisis rasio keuangan yang digunakan memiliki fungsi dan kegunaan yang cukup banyak bagi perusahaan dalam mengambil keputusan, bukan berarti rasio keuangan yang dibuat sudah menjamin 100\% kondisi dan posisi keuangan yang sesungguhnya (Kasmir, 2010).

Penggunaan analisis rasio keuangan memiliki kelemahan utama yaitu risiko yang dihadapi perusahaan dengan mengabaikan adanya biaya modal tidak diperhatikan. Untuk mengatasi kelemahan dari analisis rasio keuangan, maka dikembangkan konsep pengukuran kinerja keuangan berdasarkan nilai tambah (Value added) yaitu economicvalue added (EVA), Market Value added (MVA), dan Financial Value Added (FVA) (Sunardi, 2018).

Perusahaan, untuk situasi ini PT Garuda Indonesia Tbk, harus memiliki pilihan untuk membuat nilai tambah atau keuntungan besar dan membuat atau menambah nilai modal yang telah disumbangkan untuk memenuhi asumsi untuk pendukung keuangan (pendukung keuangan atau investor). Penting adanya investigasi pameran di PT Garuda Indonesia Tbk. Metodologi yang diambil dalam pengujian ini menggunakan strategi yang digunakan oleh eksplorasi komparatif dalam memperkirakan eksekusi menggunakan EVA, FVA dan MVA (Sunardi, 2020). Tujuan dari penelitian ini adalah untuk mengukur kinerja keuangan dengan Economic Value Added (EVA), Financial Value Added (FVA) dan Market Value Added (MVA) Hasil dari analisis ini pada akhirnya akan digunakan oleh pemodal sebagai bahan analisis sebelum membeli saham tersebut dan digunakan oleh perusahaan untuk mengetahui atau mengukur kinerja keuangan.

\section{TINJAUAN PUSTAKA}

\section{Laporan Keuangan}

Pengertian laporan keuangan menurut Ikatan Akuntansi Indonesia adalah 
struktur yang menyajikan posisi keuangan dan kinerja keuangan dalam sebuah entitas. Tujuan umum dari laporan keuangan ini untuk kepentingan umum adalah penyajian informasi mengenai kinerja keuangan (financial performance), posisi keuangan (financial position) dan arus kas (cash flow) dari suatu entitas yang berguna untuk membuat keputusan ekonomis bagi para pengguna (Dewi, 2017).

\section{Kinerja Keuangan}

Kinerja adalah suatu proses dari hasil yang mengacu dan diukur selama periode waktu tertentu berdasarkan kesepakatan atau ketentuan yang telah ditetapkan sebelumnya (Edison 2016). Kinerja keuangan merupakan suatu kinerja yang harus diukur untuk mengetahui keadaan keuangan suatu perusahaan yang digunakan sebagai dasar pengambilan keputusan bagi investor maupun pihak manajemen.

\section{Economic Value Added (EVA)}

Economic Value Added (EVA) merupakan estimasi laba ekonomi usaha yang sebenarnya untuk tahun tertentu dan sangat jauh berbeda dari laba bersih akuntansi dimana laba akuntansi tidak dikurangi dengan biaya ekuitas sementara dalam perhitungan metode Economic Value Added (EVA) biaya ini akan dikeluarkan (Brigham dan houston 2013).

\section{Financial Value Added (FVA)}

Financial Value Added(FVA) Merupakan Pengukuran Kinerja perusahaan yang mengukur nilai tambah financial suatu perusahaan yang mempertimbangkan konstribusi fixed assets dalam menghasilkan keuntungan bersih perusahaan (Butar 2017). Financial Value Added (FVA) merupakan suatu metode baru yang saat ini mulai menggeser posisi EVA dalam mengukur kinerja dan nilai tambah perusahaan.

\section{Market Value Added (MVA)}

Selain konsep EVA, penilaian kinerja perusahaan juga dapat dilakukan dengan menggunakan konsep MVA. Menurut Brigham dan Houston (2010) Market Value Added adalah perbedaan antara nilai pasar ekuitas suatu perusahaan dengan nilai buku seperti yang disajikan dalam neraca, nilai pasar dihitung dengan mengalikan harga saham dengan jumlah saham yang berada.Model MVA tersebut untuk pengukur kinerja yang sifatnya eksternal, dan hanya dapat diukur ketika perusahaan telahgo public. Hal tersebut yang menyebabkan nilai MVA cenderung memberikan penilaian yang lebih besar dari tambahan kekayaan investasi yang sesungguhnya terjadi (Felisia, 2011). 


\section{METODE PENELITIAN}

Penelitian ini merupakan penelitian deskriptif dengan pendekatan kuantitatif (Sugiyono, 2011). Sumber data penelitian ini menggunakan sumber data sekunder eksternal diperoleh malalui studi kepustakaan yang tersusun dalam bentuk dokumen yaitu berupa laporan keuangan. Teknik analisis dalam penelitian ini menggunakan Time Series Analysis.

\section{HASIL DAN PEMBAHASAN}

Hasil pengukuran EVA PT Garuda Indonesia di tahun 2015 adalah sebesar 8.648.619,39 yang artinya karena EVA > 0 maka menunjukkan bahwa ditahun 2015 telah terjadi proses nilai tambah pada perusahaan dan berhasil menciptakan nilai bagi penyedia dana. ditahun 2016 hasil pengukuran EVA sebesar -21.805.114,3 yang artinya karena EVA $<0$ maka menunjukkan tidak terjadinya proses nilai tambah karena laba yang tersedia tidak dapat memenuhi harapan para investor. Ditahun 2017 hasil pengukuran EVA sebesar-116.213.094,7 yang artinya EVA<0 maka menunjukkan tidak terjadinya proses nilai tambah karena laba yang tersedia tidak dapat memenuhi harapan para investor. Ditahun 2018 hasil pengukuran EVA sebesar -9.637.990,73 yang artinya EVA $<0$ maka menunjukkan tidak terjadinya proses nilai tambah karena laba yang tersedia tidak dapat memenuhi harapan para investor. Ditahun 2019 hasil pengukuran EVA sebesar 12.548.576,1 yang artinya karena EVA $>0$ maka menunjukkan bahwa ditahun 2019 telah terjadi proses nilai tambah pada perusahaan dan berhasil menciptakan nilai bagi penyedia dana.

Tabel 1

Menghitung Komponen EVA (Economic Value Added)

$\mathrm{EVA}=$ NOPAT $-($ WACC $\mathrm{x}$ IC)

Komponen Eva Rumus

\begin{tabular}{ll} 
NOPAT & Pendapatan Usaha Bersih (1-Tarif Pajak) \\
WACC & {$[(\mathrm{D} \times \mathrm{rd})(1-\mathrm{tax})+(\mathrm{E} \times \mathrm{re})]$} \\
IC & (Total Hutang + Ekuitas $)-$ Hutang Jangka Pendek \\
EVA & NOPAT - WACC $\mathrm{x}$ IC \\
\hline
\end{tabular}

Tabel 2

Perhitungan EVA (Economic Value Added) PT. Garuda Indonesia Tbk 2015-2019 (USD)

\begin{tabular}{lrrrrr} 
& \multicolumn{4}{c}{ Tahun } \\
\multicolumn{1}{c}{ Keterangan } & 2015 & 2016 & 2017 & \multicolumn{1}{c}{2018} \\
NOPAT & $123.363 .042,09$ & $46.936 .552,8$ & $76.181 .177,3$ & $26.610 .338,3$ & $18.166 .443,3$ \\
Capital Charges & $114.714 .422,7$ & $68.741 .667,1$ & $192.394 .272,4$ & $36.248 .329,03$ & $5.617 .867,2$ \\
EVA & $8.648 .619,39$ & $-21.805 .114,3$ & $-116.213 .094,7$ & $-9.637 .990,73$ & $12.548 .576,1$ \\
\hline
\end{tabular}

Sumber : Hasil Olah Penelitian, 2021 


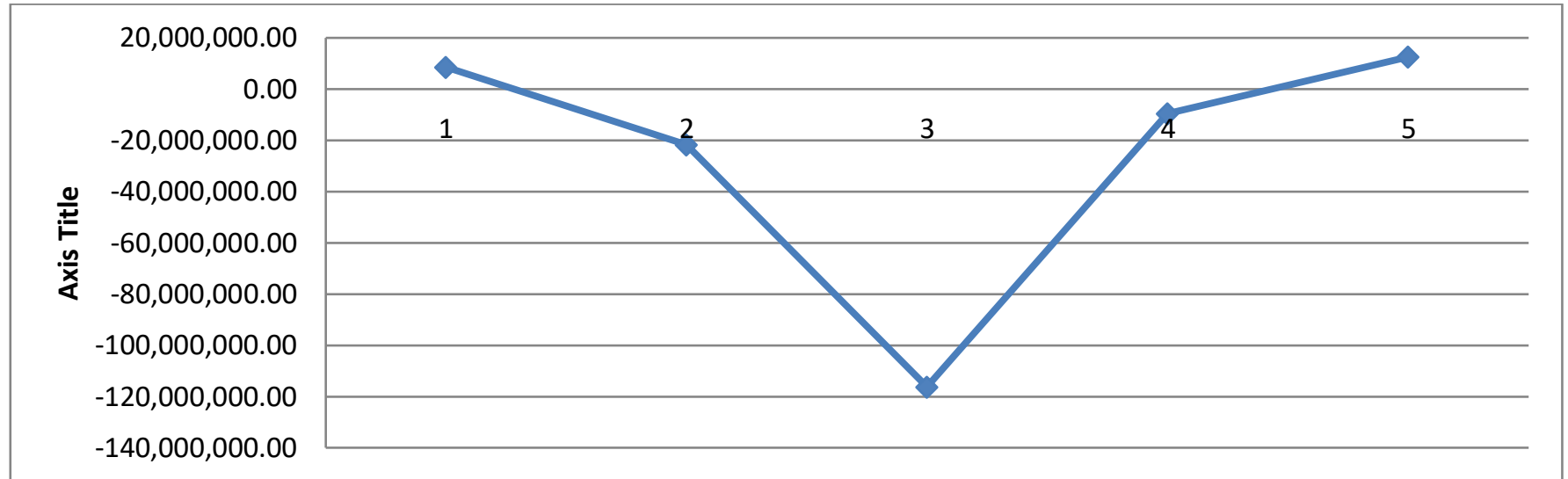

Sumber : Hasil Olah Penelitian, 2021

Gambar 1

Diagram EVA PT. Garuda Indonesia Tbk 2015-2019

Hasil pengukuran FVA PT Garuda Indonesia Tbk di tahun 2015 sebesar 9.466.269,39 yang artinya karena FVA > 0 maka menunjukkan bahwa terjadi nilai tambah financial bagi perusahaan. Di tahun 2016 hasil pengukuran FVA sebesar $-21.303 .444,5$ yang artinya karena FVA <0 maka menunjukkan bahwa tidak terjadi nilai tambah financial bagi perusahaan. Di tahun 2017 hasil pengukuran FVA sebesar $74.271 .681,28$ yang artinya karena FVA > 0 maka menunjukkan bahwa terjadi nilai tambah financial bagi perusahaan. Di tahun 2018 hasil pengukuran FVA sebesar 26.250.725 yang artinya karena FVA > 0 maka menunjukkan bahwa terjadi nilai tambah financial bagi perusahaan. Di tahun 2019 hasil pengukuran FVA sebesar 18.110.735,6 yang artinya karena FVA>0 maka menunjukkan bahwa terjadi nilai tambah financial bagi perusahaan.

Tabel 3

Perhitungan FVA (Financial Value Added) PT. Garuda Indonesia Tbk2015-2019 (USD)

\begin{tabular}{lrrrrr}
\multicolumn{1}{c}{ Keterangan } & \multicolumn{5}{c}{ Tahun } \\
& \multicolumn{1}{c}{2015} & 2016 & \multicolumn{1}{c}{2017} & \multicolumn{1}{c}{2018} & \multicolumn{1}{c}{2019} \\
NOPAT & 123.363 .042 & $46.936 .552,8$ & $76.181 .177,3$ & 26.610 .338 & $18.166 .443,3$ \\
ED & $114.714 .422,79$ & $68.741 .667,16$ & $1.923 .942,72$ & $362.483,29$ & $56.178,67$ \\
D & 0,71277 & 0,72979 & 0,75089 & 0,79179 & 0,83828 \\
FVA & $9.466 .269,39$ & $-21.303 .444,5$ & $74.271 .681,28$ & 26.250 .725 & $18.110 .735,6$ \\
\hline
\end{tabular}

Sumber : Hasil Olah Penelitian, 2021 


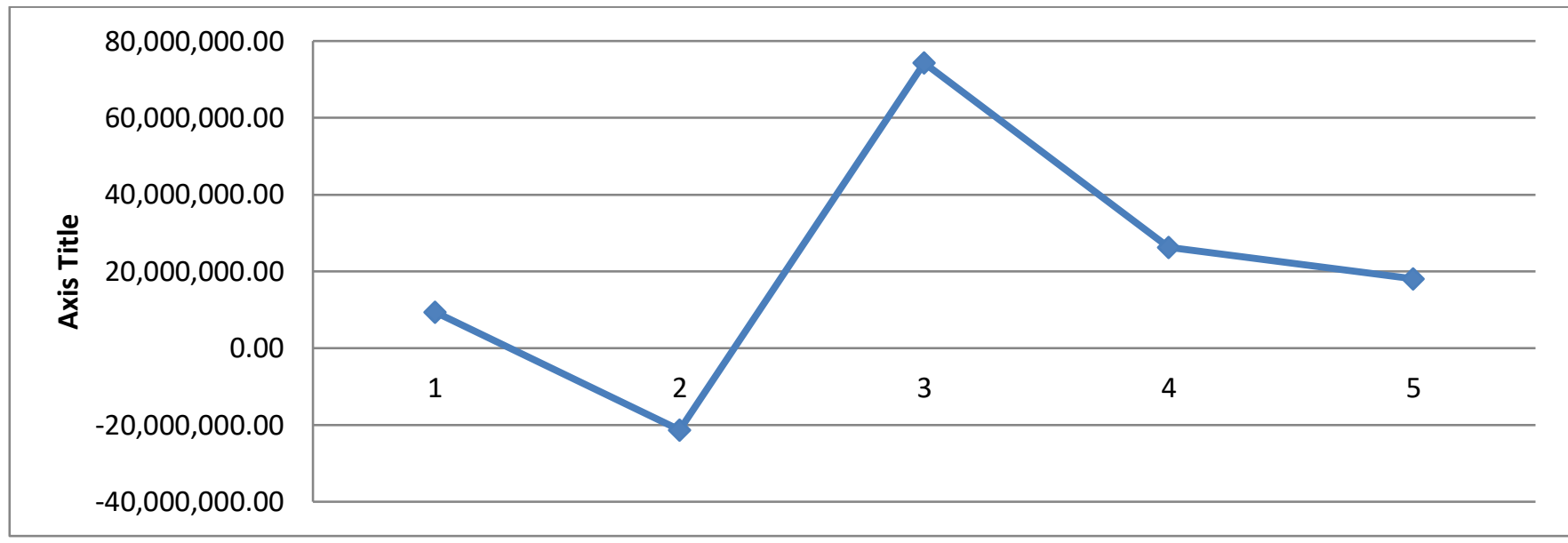

Sumber : Hasil Olah Penelitian, 2021

Gambar 2

Diagram FVA PT. Garuda Indonesia Tbk 2015-2019

Hasil pengukuran MVA PT Garuda Indonesia Tbk $2015 \quad$ yaitu 7.991.384.167.423 yang artinya karena MVA $>0$ maka menunjukkan bahwa ditahun 2015 pihak manajemen perusahaan telah mampu meningkatkan kekayaan perusahaan dan para pemegang saham atau bias dikatakan kinerja perusahaan tersebut baik. Ditahun 2016 hasil pengukuran MVA yaitu 8.741.523.208.347 yang artinya karena MVA $>0$ maka menunjukkan bahwa pihak manajemen perusahaan telah mampu meningkatkan kekayaan perusahaan dan para pemegang saham atau bias dikatakan kinerja perusahaan tersebut baik. Ditahun 2017 hasil pengukuran MVA yaitu 7.764.131.429.954 yang artinya MVA>0. menunjukkan bahwa pihak manajemen perusahaan telah mampu meningkatkan kekayaan perusahaan dan para pemegang saham atau bias dikatakan kinerja perusahaan tersebut baik. Ditahun 2018 hasil pengukuran MVA yaitu 7.712.279.180.370 yang artinya karena MVA>0 maka menunjukkan bahwa pihak manajemen perusahaan telah mampu meningkatkan kekayaan perusahaan dan para pemegang saham atau bias dikatakan kinerja perusahaan tersebut baik. Ditahun 2019 hasil pengukuran MVA yaitu 12.890.317.134.487 yang artinya MVA $>0$ maka menunjukkan bahwa pihak manajemen perusahaan telah mampu meningkatkan kekayaan perusahaan dan para pemegang saham atau bias dikatakan kinerja perusahaan tersebut baik. 
Tabel 4

Menghitung komponen MVA

MVA = Nilai perusahaan - Modal yang diinvestasikan
$\begin{array}{ll}\text { Komoponen MVA } & \text { Rumus } \\ \text { Nilai Perusahaan } & \text { Jumlah saham yang beredar x Harga saham } \\ \text { IC } & \text { (Total Hutang + Ekuitas) - Hutang Jangka Pendek } \\ \text { MVA } & \text { Nilai Perusahaan - IC (Modal yang diinvestasikan }\end{array}$

Tabel 5

Perhitungan MVA (Market Value Added) PT Garuda Indonesia Tbk 2015-2019 (USD)

\begin{tabular}{|c|c|c|c|c|c|}
\hline \multirow{2}{*}{ Keterangan } & \multicolumn{5}{|c|}{ Tahun } \\
\hline & 2015 & 2016 & 2017 & 2018 & 2019 \\
\hline Nilai & 7.993.498.329 & 8.743.697.201. & 7.765 .972 .87 & 7.714 .199 .72 & 12.891 .514 .973 \\
\hline Perusahaan & .288 & 616 & 5.900 & 3.394 & 994 \\
\hline $\begin{array}{l}\text { Modal yang } \\
\text { diinvestasikan }\end{array}$ & 2.114 .161 .865 & 3.173 .993 .269 & 1.841 .445 .946 & 1.920 .543 .024 & 1.197 .839 .507 \\
\hline MVA & 7.991.384.167. & 8.741 .523 .208 .3 & 7.764 .131 .429 & 7.712 .279 .180 & 12.890 .317 .134 .4 \\
\hline & 423 & 47 & .954 & .370 & 87 \\
\hline
\end{tabular}

Sumber : Hasil Olah Penelitian, 2021

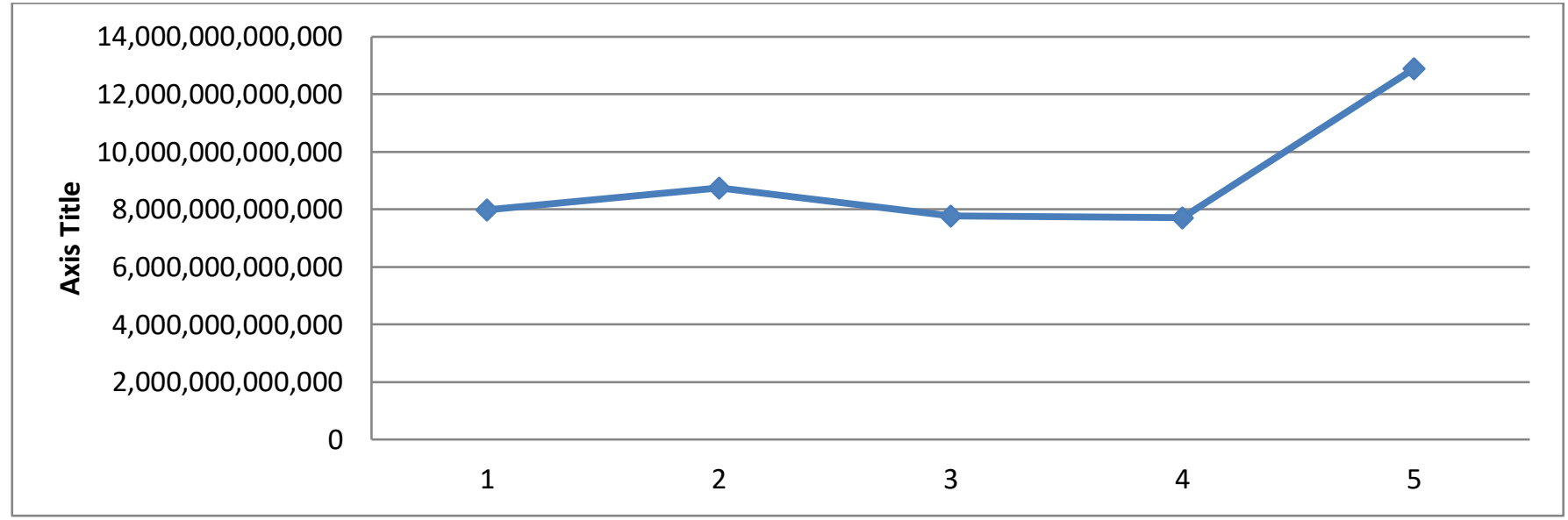

Sumber : Hasil Olah Penelitian, 2021

Gambar 3

Diagram MVA PT. Garuda Indonesia Tbk 2015-2019

Evaluasi Kinerja Keuangan dengan menggunakan Economic Value Added (EVA), Financial Value Added (FVA), Market Value Added (MVA) dengan Pendekatan Time Series

Berdasarkan hasil perhitungan EVA pada tabel 2, nilai rata-rata EVA pada PT.
Garuda Indonesia Tbk pada tahun 20152019 adalah negatif ini berarti perusahaan tidak mampu memberikan nilai tambah bagi para pemegang sahamnya, karena nilai EVA bernilai negative $(\mathrm{EVA}<0)$ sehingga dikatakan berkinerja tidak baik. Economic Value Added PT Garuda 
Indonesia Tbk periode tahun 2015-2019 mengalami penurunan dari tahun 20152018 mengalami penurunan. Hal ini disebabkan adanya peningkatan biaya modal dan menunjukkan bahwa perusahaan dapat memberikan pengembalian investasi sesuai dengan harapan investornya. Dari tabel diatas terlihat rata-rata Economic Value Added (EVA) yaitu -25.291.800,85, hal ini mengindikasikan bahwa perusahaan belum mampu memberikan nilai tambah bagi para pemegang saham karena EVA bernilai Negatif $\quad(E V A<0) \quad$ sehingga dikatakan berkinerja Tidak Baik

Berdasarkan hasil perhitungan FVA pada tabel 3, nilai rata-rata FVA pada PT. Garuda Indonesia Tbk pada tahun 20152019 adalah Positif ini berarti perusahaan mampu memberikan nilai tambah financial bagi perusahaan dan bagi para pemegang sahamnya karena nilai FVA bernilai positif (FVA $>0)$ sehingga dikatakan berkinerja dengan Baik. Financial Value Added (FVA) PT Garuda Indonesia Tbk periode tahun 2015-2019 mengalami penurunan pada tahun 2015-2016 namun ditahun 20172019 mengalami peningkatan ini berarti secara trend terjadi kenaikan. Sehingga menunjukkan bahwa perusahaan dapat memberikan keuntungan bagi investasi sehingga sesuai dengan harapan investornya. Dari tabel diatas terlihat ratarata Financial Value Added (FVA) yaitu 21.359.193,35, hal ini mengindikasikan bahwa perusahaan mampu memberikan nilai tambah financial bagi perusahaan dan investor karena nilai FVA bernilai Positif $(\mathrm{FVA}>0)$ sehingga dikatakan berkinerja dengan Baik.

Berdasarkan hasil perhitungan MVA pada tabel 5, nilai rata-rata MVA pada PT. Garuda Indonesia Tbk pada tahun 20152019 adalah positif ini berarti perusahaan mampu memberikan nilai tambah bagi perusahaan dan bagi para pemegang sahamnya karena nilai MVA bernilai positif $(\mathrm{MVA}>0)$ sehingga dikatakan berkinerja dengan Baik. Market Value Added (MVA) PT Garuda Indonesia Tbk periode tahun 20152019 mengalami kenaikan sehingga menunjukkan bahwa perusahaan dalam hal ini mampu memberikan keuntungan bagi para pemegang saham sehingga sesuai dengan yang diharapkan oleh para investor. Dari tabel diatas terlihat rata-rata Market Value Added (MVA) yaitu 9.019.927.024.116, hal ini mengindikasikan bahwa perusahaan mampu memberikan nilai tambah karena nilai MVA bernilai Positif (MVA $>0$ ) sehingga dikatakan berkinerja dengan Baik. 
Tabel 6

Perhitungan rata-rata EVA, FVA, MVA

\begin{tabular}{lrrr} 
Tahun & \multicolumn{3}{c}{ PT. Garuda Indonesia Tbk } \\
2015 & \multicolumn{1}{c}{ EVA } & \multicolumn{1}{c}{ FVA } & \multicolumn{1}{c}{ MVA } \\
2016 & $8.648 .619,39$ & $9.466 .269,39$ & 7.991 .384 .167 .423 \\
2017 & $-21.805 .114,3$ & $-21303.444,5$ & 8.741 .523 .208 .347 \\
2018 & $-116.213 .094,7$ & $74.271 .681,28$ & 7.764 .131 .429 .954 \\
2019 & $-9.637 .990,73$ & 26.250 .725 & 7.712 .279 .180 .370 \\
\hline Rata-rata & $12.548 .576,1$ & $18.110 .735,6$ & 12.890 .317 .134 .487 \\
\hline Kinerja & $-25.291 .800,85$ & $21.359 .193,35$ & 9.019 .927 .024 .116 \\
\hline
\end{tabular}

Sumber : Hasil Olah Penelitian, 2021

\section{KESIMPULAN}

Hasil pengukuran EVA dengan pendekatan time series dari tahun 2015-2019 rata-rata EVA adalah sebesar -25.291.800,85 hal ini mengindikasikan bahwa perusahaan belum mampu memberikan nilai tambah bagi para pemegang saham karena EVA bernilai Negatif (EVA < 0) sehingga dikatakan berkinerja Tidak Baik. Hasil Pengukuran FVA dengan pendekatan time series dari tahun 2015-2019 rata-rata FVA adalah sebesar 21.359.193,35 hal ini mengindikasikan bahwa perusahaan mampu memberikan nilai tambah financial bagi perusahaan dan investor karena nilai FVA bernilai Positif (FVA > 0) sehingga dikatakan berkinerja Baik Hasil pengukuran MVA dengan pendekatan time series dari tahun 2015-2019 rata-rata MVA adalah sebesar 9.019.927.024.116, hal ini mengindikasikan bahwa perusahaan mampu memberikan nilai tambah karena nilai MVA bernilai Positif (MVA > 0) sehingga dikatakan berkinerja Baik.

\section{DAFTAR PUSTAKA}

Brigham,Houston. 2010. Dasar-dasar Manajemen Keuangan Buku 1 (Edisi II). Jakarta : Salemba Empat.

Brigham, Eugene dan Houston. 2013. Fundamentals Of Management, Dasar- Dasar Manajemen Keuangan, Edisi 10, buku pertama. Jakarta: Salemba Empat

Butar, Lasti. 2017. Analisis Kinerja Keuangan Menggunakan Pendekatan Economic Value Added (EVA) dan Market Value Added (MVA) Pada Perusahaan BUMN Sektor Pertambangan yang Terdaftar Di BEI Periode 2011-2015.

Dewi, Meutia. 2017. Penilaian Kinerja Keuangan Perusahaan dengan Menggunakan Metode EVA (Economic Value Added) Studi Kasus Pada PT. Krakatau Steel Tbk Periode 2012-2016. Vol. 6 No 1 (2017) : Jurnal Manajemen dan Keuangan. Universitas Samudra. 
Edison, Anwar, Komariyah. 2016. Manajemen Sumber Daya Manusia. Edisi Pertama. Alfabeta. Bandung.

Felisia. 2011. Pengukuran Kinerja Keuangan dengan Pendekatan EVA (Economic Value Added) dan FVA (Financial Value Added). Vol. 15 No.2 (2011). Universitas Katolik Parahyangan Indonesia.

Harahap, Sofyan Stafri. 2013. Analisis Kritis Atas Laporan Keuangan. Rajawali Pers, Jakarta.

Kasmir. 2010. Pengantar Manajemen Keuangan. Eedisi pertama. Jakarta: Kencana Prenada Media Group.

Rahayu, Sri. 2010. Pengaruh Kinerja Keuangan Terhadap Nilai Perusahaan Dengan Pengungkapan Corporate Social Respocibility dan Good Corporate Govermance sebagai Variabel Pemoderesi Universitas Diponegoro, Semarang.

Sugiyono. 2011. Metode Penelitian Kuantitatif Kualitatif dan R\&D. Bandung: Alfabeta

Sunardi, Nardi. 2020. Penilaian Kinerja Keuangan menggunakan Economic Value Added (EVA) dan Market Value Added (MVA) dengan Time Series Approach pada Industri Semen di Indonesia. Vol 3, No 2, Januari 2020. Hal 187-196.

Sunardi, Nardi. 2018. Analisis Economic Value Added (EVA), Financial Value Added (FVA) dan Market Value Added (MVA) dengan Time Series Approach Sebagai Alat Penilaian Kinerja Keuangan (Studi Pada Industri Konstruksi (BUMN) di Indonesia Yang Listing di BEI Tahun 2013-2017) Jurnal Sekuritas, Vol 2, No 1, September 2018. 